\title{
Autonomous Reboot: Kant, the categorical imperative, and contemporary challenges for machine ethicists
}

\author{
Jeffrey White ${ }^{1,2}$
}

Received: 6 January 2020 / Accepted: 6 July 2020 / Published online: 20 January 2021

(c) The Author(s) 2021

\begin{abstract}
Ryan Tonkens (2009) has issued a seemingly impossible challenge, to articulate a comprehensive ethical framework within which artificial moral agents (AMAs) satisfy a Kantian inspired recipe—"rational" and "free"—while also satisfying perceived prerogatives of machine ethicists to facilitate the creation of AMAs that are perfectly and not merely reliably ethical. This series of papers meets this challenge by landscaping traditional moral theory in resolution of a comprehensive account of moral agency. The first paper established the challenge and set out autonomy in Aristotelian terms. The present paper interprets Kantian moral theory on the basis of the preceding introduction, argues contra Tonkens that an engineer does not violate the categorical imperative in creating Kantian AMAs, and proposes that a Kantian AMA is not only a possible goal for Machine ethics research, but a necessary one.
\end{abstract}

Keywords Autonomy $\cdot$ Artificial moral agent $\cdot$ AMA $\cdot$ Machine ethics $\cdot$ Kant

\section{Introduction}

And when everyone contends to achieve what is fine and strains to do the finest actions, everything that is right will be done for the common good, and each person individually will receive the greatest of goods, since that is the character of virtue.

- Aristotle ${ }^{1}$

This series of papers answers Ryan Tonkens' (2009) challenge for machine ethicists to conceive of a Kantian moral agent without violating Kantian moral principles at the same time. ${ }^{2}$ Tonkens argues for the impossibility of an AMA constrained by Kant's categorical imperative and motivated by his concept of duty, a "full ethical agent" with the characteristic mark thereof consisting in "the capacity for selfdirected action-i.e., "rationality" and "personal freedom (or autonomy)" (p. 426). The preceding paper introduced

Jeffrey White

jeffreywhitephd@gmail.com

1 Department of Philosophy, The University of Twente, P.O. Box 217, 7500 AE Enschede, The Netherlands

2 Cognitive neurorobotics research unit, Okinawa Institute of Science and Technology Graduate University, 1919-1 Tancha, Onna-son, Okinawa 904-0495, Japan
Aristotle's philosophy in order to understand what autonomy means for Kant, as it is from this inheritance that his own work advances. The present paper begins with where the last left off. With Aristotle's moral excellence understood in terms of custom, Kant offers an account of morality that is not context dependent. This section quickly exposes this purpose. Section 2 offers an interpretation of Kantian moral theory in answer to Tonkens' challenge to conceive of a Kantian AMA. Section 3 argues that-contrary to Tonkens' assertions otherwise - nothing in Kantian ethics forbids such an AMA, but rather motivates it. Section 4 reviews Tonkens' challenge from the categorical imperative-effectively that to create a Kantian AMA would be to violate the categorical imperative-and argues from Lazlo Versenyi's (1974) categorical requirement for the construction of Kantian AMAs directly contrary to Tonkens' categorical requirement against it. Following this line of reasoning, Sect. 5 concludes that a Kantian AMA — dignified, respected, autonomous—is

\footnotetext{
${ }^{1}$ NE, Book 9, chapter 6, 1169a9-12, p. 428. Quoted translations of Aristotle are taken from Aristoteles, Fine and Irwin (1995) unless indicated otherwise. All references are indicated by their Bekker numbers so that readers can find them as reproduced in other resources. Nicomachean Ethics is abbreviated NE.

2 All references to Tonkens are from Tonkens (2009) and are typically referenced as "Tonkens" hereafter.
} 
not only a possible target for Machine ethics research, but a necessary one.

From the beginning, it is important to keep the preceding paper's Aristotelian portrait of moral agency in mind. For Aristotle and the Greeks, economics was the art of organizing a household, with statecraft balancing internal with external requirements of the flourishing community understood effectively as a household writ large. But, economies can be poorly ordered, servants misused, healthy balances upset, and injustice endemic. This is why Aristotle's statecraft is an art, even though politics may be the subject of a science. And this is also why Kant is so interested in the natural forces at play in the hearts of individual members of humankind, "starry heavens above" and "moral law within" and all that (cf. discussion beginning 5:161-5:162 in Kant 1996, p. 269): to account for the orientation toward the good in a world where simply following (potentially) corrupted social-political orders is not good enough. ${ }^{3}$

As we found in the last paper, Aristotle opens the door to this orientation in the inculcation of the pro-immortal standpoint. But, he does not show how someone might conceive of this inner self-relationship in a way that may clearly inform the construction of an AMA. Kant picks up the task of exposing the subjective sense of being confronted with such a point of view, what he eventually describes in terms of one's relationship with universal moral law. "Kant is mostly concerned with explaining the fundamental difficulty we encounter in attempting to think the relation between the moral law ... and actions that unfold in the sensible world", a task made more difficult given that "an external event, given in space and time, does not by itself give us any access to the internal motivation of the agent" (Longuenesse 2005, p. 237, see also Kant, 4:389 and 5:145 in 1996, pp. 45 and 256 , respectively, as well as "The analytic of practical reason" beginning 5:57). In order to clarify this relationship, he employs the familiar model of the sovereign King or Queen (cf. Reath 2006). Here, we may recall the "kingly" disposition from which the Aristotelian agent acts, with right reason uninhibited by passions (as discussed in Sect. 3 of the preceding paper).

Kant advances on this received account for an increasingly liberal largely Christian Europe two millennia later, moving from ideal political community as object of a free ruling class to ideally ethical collective as personal aim for autonomous moral perfectionists dignified by just such a

\footnotetext{
3 Consider Kant's affinity for Rousseau in this context. All quotations are taken from Kant (1996) unless otherwise specified, with first citations in each paragraph indicated by 1996, page number, later citations with page number only. All references include Akademie volume: page number so that readers can find them in other resources. Where useful, citations point to volume and chapter rather than single passage or page.
}

kingly, self-sovereign, disposition. For example, he observed that the "Greek schools could never solve their problem of the practical possibility of the highest good" because they mistook the measure of moral worth as either too greatly shaped by human sensible desire or too distant from it" (see discussion beginning 5:126, 1996, p. 241; see also Sect. 4 of the preceding paper). On his analysis, Aristotle's rational descendants in the Stoics held their sage to unreasonable alienation from the human condition, while the Epicureans, on the other hand, made each his own measure and motive ideal.

Here, we find Kant having set to work in solving this problem of the practical possibility of the highest good by reconciling these diverging interpretations of the common tradition. It is in this context that we can understand why Kant's "highest good" consists in the "union " and "harmony" of "human morality" and "human happiness" (cf. Chapter II, 5:110, p. 228, see also 5.64, pp. 191-2) in the relationship between the summum bonum and the individual moral aspirant (again, see also discussion beginning 5:161-5:162). Moreover, it is in this context that one must ultimately assess the potential for the conception of a Kantian AMA distinct from any other, including an Aristotelian AMA. For instance, where Aristotle tells us that the free person is motivated to understanding for the sake of the highest parts of him/herself, Kantian autonomy is motivated by "the genuine moral incentive" which.

"is nothing other than the pure moral law [as it] subjectively effects respect for their higher vocation in human beings, who are at the same time conscious of their sensible existence and of the dependence, connected with it, on their pathologically affected nature." (5:88, Kant 1996 p. 211).

Resolving the "moral law" as representative of this "higher vocation" relative to the human "pathologically affected nature" is central in Kant's theory (cf. The Critique of Practical Reason, chapter 3 "On the incentives of pure practical reason" beginning 5:71 and ending 5:89) and represents his advance over his inherited tradition, including the exposition of the motivation to the common good that Aristotle sketches in terms of virtue (or the pathological lack thereof) for the political animal, citizen, slave, and ruler. The next section uncovers the essential motivational dynamics that arise in this fundamental inner self-relation so that we may formally conceive of a Kantian AMA, thereby answering the first part of Tonkens' challenge. 


\section{What is morality for Kant?}

The point of Kantian ethics is that the vocation of the human race is to refashion itself, opposing its naturalsocial impulses that lead to competition and discord, and fostering instead a realm of ends, in which rational beings act according to those laws which bring their ends into necessary agreement in an organic system. - Allen Wood ${ }^{4}$

As in Aristotle, Kant locates freedom in the capacity to move according to intellect contrary to immediate desire in the interests of justice, a capacity unnecessary in God and absent in "one free from all sensibility" $(5: 76,1996$, p. 201, compare with Aristotle 1253a2-1253b for example). ${ }^{5}$ This capacity is most clearly exemplified in human beings in one particular form of political life, that of the sovereign King or Queen worthy of reverence and respect rather than a tyrant and despot. Where the tyrant employs power including superior predictive capacities to order society around selfish ends, the revered King or Queen is free from such short-term desires and so-autonomous-is able to make and enforce laws for the long-term good of the incorporated community of persons over which either sits sovereign. Kant effectively liberates this model to suit his increasingly liberal society. Thus, the Kantian moral agent is sovereign over itself, making and enforcing self-regulating laws in the interests of the incorporated community of moral agents writ largest.

Kant employs the model sovereign King or Queen in order to clarify autonomy as the capacity to govern one's self through self-given law (see for example discussion beginning 4:446, 1996, p. 94-96). As noted in Sect. 3 of the preceding paper, personhood was traditionally dependent on role within political community. Of all of the members of a community, monarchs, statesmen, and legislators play special roles in the creation of laws that regulate action in the long-term best interests of what Aristotle associated with the highest good of the self-sufficient community, perhaps helping to explain why Aristotle afforded these roles such attention. Kant effectively casts all persons in the role of legislator, sovereign over themselves while still responsible for the way that the world turns out for others sharing this role. So, on his account "persons" are "self-legislating" "rational

\footnotetext{
$\overline{4 \text { Wood } 1999}$, p. 8.

5 The complete passage reads: "With regard to this it should be noted that, since respect is an effect on feeling and hence on the sensibility of a rational being, it presupposes this sensibility and so too the finitude of such beings on whom the moral law imposes respect, and that respect for the law cannot be attributed to a supreme being or even to one free from all sensibility, in whom this cannot be an obstacle to practical reason." $(5: 76,1996$, p. 201) A heteronymous nature is essential to autonomy.
}

beings" and "ends in themselves" marked by the characteristic capacity "to further the ends of others" contrary to selfish desires otherwise (4:428, 4:430-4.431, p. 78, see especially "On the incentives of pure practical reason" beginning 5:71, and 8:279, p. 562; compare Aristotle 1097a28-1097b8, 1068a33-35). As the monarch over a nation-state is able to create laws and to judge what is good and bad on the basis of what is best for the kingdom as a whole, the Kantian rational agent is "a member" of "namely ... a kingdom of ends" who also is able "to appraise himself and his actions from this point of view" (original emphasis, 4:433, p. 83, note also duty to self-mastery, e.g., 5:109, p. 227). The relationship that this sets up within the agent recalls Aristotle's pro-immortality. Clarifying this relationship is crucial for the purpose of meeting Tonkens' (2009) challenge.

Taking up this point of view-from the kingdom of ends-depends on the native capacity of the "will" to "take a different standpoint when by means of freedom we think ourselves as causes efficient a priori" rather than as "effects that we see before our eyes" (4:450, 1996, p. 98, see also 5:73, and "Critical resolution of the antimony of pure practical reason" beginning at 5:114, p. 231), a capacity which Kant associates with rationality. Rationality recalls Aristotle's right reason, as its exercise depends on independence from "alien causes determining it" (4:446, 1996, p. 94). Accordingly, rational agents are potentially free. However, Aristotle is focused on exposing for the statesman what is universal to self-standing political systems, that they themselves depend on constituent virtue, and he offers an analysis of moral excellence in terms of custom specific to roles within resident communities accordingly (cf. 1185b39-1186a4).

Though Aristotle recognizes the superiority of the ideal community composed of the best constituents, he neglects the possibility because it is impractical. Most people don't act from right reason and goodwill. Becoming accustomed, habituated, changes the character of a person, with moral excellence understood to vary depending on social-political context of habituation and with the task for the statesman and legislator being how to understand this context and inform these habits. Kant, on the other hand, forces us to focus on the potential for autonomy nascent in the embodied structural dynamic that is the essence of rationality in every individual. Rather than think as the statesman who must order the system to externally orient each co-dependent constituent through clever economics, Kant casts each constituent as his or her own "freely acting cause" insofar as each can consider potential alternatives-however impractical these may appear. Then, upon choosing an ideal situation, one depends on practical reason to determine how to get there. In this way, Kant makes "the concept of freedom a regulative principle of reason" (5:48-5:49, pp. 178-179, see also 5:116, p. 233) for each member, not of a political class or community, but of the category of rational beings 
essentially capable of binding themselves to self-chosen ends in this way.

Of particular interest for the potential engineer of Kantian AMAs are the mechanical details of these inner dynamics calling such agents forward to their "higher vocations." On Kant's account, these dynamics involve first conceiving ourselves as free, to "detach ourselves from all empirical interests" $(4: 450,1996$, p. 97) as if "immortal" and to hold out as an ideal end a situation of "a nature in which pure reason, if it were accompanied with suitable physical power, would produce the highest good" $(5: 43$, p. 175 , see also $4: 434$, p. 83), i.e., that would make the highest moral aspirations of one's inner causality an actuality in the present, empirical obstacles notwithstanding. So understood, when we "conceive ourselves as free" we "transfer ourselves into the world of understanding as members of it and recognize the autonomy of the will with its consequence, morality" (4:453, p. 100), a process which "lets us cognize something of it, namely a law" $(5: 43$, p. 174) expressing "nothing other than the autonomy of pure practical reason ... freedom" (original emphasis, 5:33, p. 166) according to which the agent afterward exhibits a tendency to conform (see for example 5:71, p. 198, "On the incentives of pure practical reason").

Here, we may again contrast Aristotle's moral excellence as custom. Kant makes explicit Aristotle's guiding perception of understanding in terms of this essential-independently rational-capacity for autonomy rather than finding one's place within the established political order on which one's quality of life depends. Where Aristotle's political animal chooses to act according to perceptions of good and evil in the interests of its embedding community, Kant's moral agent chooses on the basis of freedom, in effect aiming for its own ideal moral self as member of an ideal moral community, however, distant, left to figure out how to get there after the fact. ${ }^{6}$ And again on the model of King or Queen, in both setting out and then falling under one's self-ascribed moral law, the autonomous agent is "sovereign" and "not subject to the will of any other" (original emphasis, 4:433, 1996, p. 83). ${ }^{7}$ Morality thus "proceeds from the concept of freedom" (cf. 5:42, pp. 173-174) such that the person acts freely, from "rational self-love" (5:73, p. 199). Self-love calls the agent to actualize its own higher vocation according to self-given moral law rather than from compulsion due to more immediate embodied desires and cultured habit, and in this way Kant attempts to overcome the deficiencies of

\footnotetext{
6 Kant is Socratic in this way.

7 Kant takes pains to show that following the analogy with the "supreme lawgiver" does not require a "dual personality" as if a relationship between two separable things (note to $6: 438,1996$, p. 560561 , cf. 5:100-5:101, 1996, pp. 220-221, also 5:132, "On the postulates of pure practical reason in general," p. 246).
}

the inherited tradition in resolving the subjective sense of the highest practical good independent of social-political contingency.

Moreover, Kant tells us what this relationship feels like, characterizing the condition in terms of the felt difference between desire and moral ideal formulated by pure practical reason. The "substance of morality" on this account"moral feeling"- arises in the difference between these two "higher and lower" faculties, for which Kant (again) posits a "susceptibility" of "free choice to be moved by pure practical reason (and its law)" in selecting for actions accordingly (original emphasis, 6:400, p. 529, cf. 5:49, 5:73, also 5:80). This difference between desire and project moral ideal is felt as "pain" because it entails the denial of desire, representing an embodied barrier to moral motivation that is both recognized as and overcome through action from "duty". ${ }^{8}$

When confronted with the difference between one's higher and lower faculties, duty "deprives self-love of its influence and self-conceit of its illusion, and thereby the hindrance to pure practical reason is lessened" so that "the relative weightiness of the law" relative the "will affected by impulses" is increased and the agent is freed to act accordingly $(5: 75,1996$, p. 201 , see also 5:87, p. 210). Duty in this way "elevates" the agent above itself (as a part of the sensible world) and "connects" the agent "with an order of things that only the understanding can think." Here, we may contrast Aristotle's worldly account of personhood in terms of and for the sake of the political community. Kantian duty represents "nothing other than personality, that is, freedom and independence from the mechanism of the whole of nature." On this account, each person is self-sovereign, "subject" to "special ... pure practical laws given by his own reason" with each subject both "belonging to the sensible world" and at the same time self-sovereign," subject to his own personality insofar as he also belongs to the intelligible world" (as member of a morally ideal project community). Finally, confronted with this fact about one's self in the form of duty felt as the substance of morality, the Kantian moral agent regards "his own nature in reference to his second and highest vocation only with reverence, and its laws with the highest respect" (preceding discussion from 5:86-5:87, p. 210).

As is plain, a Kantian AMA must experience itself as a personality detached from immediate worldly obligations, autonomous and with freedom to choose from pure

\footnotetext{
${ }^{8}$ Pain characterizes the denial of desire generally speaking. In terms of virtue and self-governance, see The Metaphysics of Morals, "Introduction to the doctrine of virtue", chapters 13-16, beginning p. 531 in Kant 1996. This has especially important implications in correction of inadequate dynamic systems accounts which neglect directed work toward personal project order. For some movement in this direction, see White and Tani (in press).
} 
and act from practical reason. But to do so, it must first experience itself as originally attached to more immediate ends including those conveniently afforded by its embedding social-political community. Without both, there is no higher vocation for the Kantian AMA, but only vocation (however high). Moreover, it is important to note the difference between action from duty and action according to duty on Kant's account. An action might be undertaken "in conformity with duty" and so "may turn out as the law prescribes" but not represent moral action if "the disposition to the action is not moral" $(5: 82,1996$, p. 206). It is not enough to simply do what duty compels one to do. An agent must feel as-if doing otherwise first, and even this is not enough to be considered moral. Duty is in such an instance felt as "obligation" (in the sense of a burden or unwanted but necessary task and constraint) as one's aims deviate from the moral ideal put forward by pure practical reason and as one's "will " must be brought into accord with it, perhaps corrected by an external force. This is still the action of an agent in the service of something besides the highest good.

On the other hand, acting from duty is freedom in the "positive" sense and is not felt as an obstacle to but rather as an opportunity for autonomous action (cf. 1996, 5:146-7, p. 257 , and $4: 447$, p. 94). So understood, "respect for the law is not the incentive to morality" $(5: 76$, p. 201) but rather "Respect for the law, which in its subjective aspect is called moral feeling, is identical with consciousness of one's duty" $(6: 464$, p. 580$)$ and

"is morality itself subjectively considered as an incentive inasmuch as pure practical reason, by rejecting all the claims of self-love in opposition with its own, supplies authority to the law, which now alone has influence." (5:76, 1996, p. 201).

Here is where we can locate the subjectivity of the moral sense as formally construed on Kant's account, in the rejection of personally embodied, selfish ends in uniquely experienced terms. To do so is to choose to be free to pursue one's highest potential rather than be constrained by political convention or personal habit. ${ }^{9}$ A Kantian AMA must both experience and understand its actions according to this logic.

Given that the substance of morality in its feeling presents as pain, being aware of one's duty to act according to moral law must also present as an object motivation that draws the agent to endure the passing discomfort—unique to each subject as that uniquely embodied end toward which each subject also aims-for the realization of its higher vocation. Duty does this work. Finally, to illustrate the effect of

\footnotetext{
9 We saw something similar in Aristotle's considerate person, but he tells us nothing of what it must feel like to enjoin this condition. Kant provides for this deficiency in that account.
}

duty on the will of a rational being so disposed, consider Kant's case of the "upright man" who is "in the greatest distress, which he could have avoided if he could only have disregarded duty" yet who is "sustained by the consciousness that he has maintained humanity in its proper dignity in his own person" because he "cannot bear to be unworthy of life in his own eyes." The resulting "inner tranquility" in "warding off the danger in sinking in personal worth" is "something in comparison and contrast with which life with all its agreeableness has no worth at all." (5:88, pp. 210-211) Thus, moral feeling presents as pain, but its disregard presents as a limit case that motivates the agent to do the right thing regardless of context, in a special way to be set out and addressed in the following sections.

\section{Autonomous reboot}

...the less the natural obstacles and the greater the obstacle from grounds of duty, so much the more is a transgression to be imputed (as culpable). Hence the state of mind of the subject, whether he committed the deed in a state of agitation or with cool deliberation, makes a difference in imputation, which has results. - Immanuel Kant ${ }^{10}$

As we can see, Kant enriches Aristotle's portrait of the virtuous political animal by setting out the dynamics internal to the agent constitutive of moral motivation. The relevant dynamic is most obvious in consideration of what is characterized as "essential duty" the "transgression of which violates the moral law in itself ... without regard to human welfare." It is toward essential duty that "we give the most perfect esteem to compliance" even "at the sacrifice of everything that could ever have value for our dearest inclinations" $(5: 158,1996$, p. 266$) .{ }^{11}$ Finally, "No other subjective principle must be assumed as incentive" (5:82, p. 206) besides "the pure moral law itself insofar as it lets us discover the sublimity of our own supersensible existence and subjectively effects respect for their higher vocation in human beings" (5:88, p. 211).

Tension between lower and higher faculties, embodied desire and intellect, the "sensible" and the "supersensible," accounts for why people often do the wrong things, and forms the basis for Kant's "principle of the autonomy of the will" (4:433, 1996, p. 82). The person "who acts in accordance with duty and need not wait upon the effect of

\footnotetext{
${ }_{10} 6: 228$, Kant 1996, p. 382.

11 Here again, the value is that we feel "elevated" when "we can convince ourselves, in it, that human nature is capable of so great an elevation above every incentive that nature can oppose to it." (5:158, 1996, p. 266).
} 
his action" acts from "goodwill" and "insofar as it and not the hoped-for effect is the determining ground of the will" it is "already present in the person himself" constituting the "preeminent good we call moral" (4:401, p. 56; cf. Section 3 of the preceding paper concerning Aristotle's best and most complete virtue). The "absolutely good will" is one "whose maxim can always contain itself regarded as a universal law" (4:447, p. 95), "holy" (cf. 4:414, p. 67), with the ultimate aim of this will being "to furnish the sensible world ... with the form of a world of the understanding" (5:43, p. 174), i.e., to create the kingdom of ends on Earth as an ideal situation by and for similarly motivated agents. ${ }^{12}$

As with Aristotle's political animal, Kant's rational being adopts the perspective of the "whole ... prior to the part" and-when choosing well-aims for the best for it. As we have seen, it is up to the free Aristotelian agent to develop this singular virtue under the guise of practical wisdom appropriate to the statesman and ruler. Kant goes further, exposing these motivational dynamics as common to every human being and bringing the responsibility for the development of autonomy, as well as the practical reason necessary for its exercise, home to each of them individually:

"A human being has a duty to carry the cultivation of his will up to the purest virtuous disposition, in which the law becomes also the incentive to his actions that conform with duty and he obeys the law from duty. This disposition is inner morally practical perfection.

... Yet it is a moral perfection, by which one makes one's object every particular end that is also a duty." (6:387, 1996, pp. 518-519).

Though far from transparently reliable, this is the algorithm through which project ends are populated for a Kantian agent regardless of station. The Kantian AMA is motivated to moral perfection as a member of a project ideal

\footnotetext{
12 Opportunities to do so in turn depend on the condition of the community into which the individual is born (cf. Heidegger 1996, on "thrownnesss"). We find this implication in Aristotle when he says that the political community is "prior" to the household, and the household to the individual (1253a19). Human happiness is dependent on circumstance, fortune and good health, good education and opportunities for experience for example, but especially it depends on opportunity for reflection in a stable environment, leisure, Plato's famous chair. In so far as these are available, the state of a person's character may be voluntarily determined through deliberation, decision, and action with resulting experience informing habit according to which a person may at every instance either continue or desist unless no longer free (cf. NE, Book 3, chapter 5, 1113b4-1115a4, esp. 1114b30). The problem is that for Aristotle most people are not born free, so their character is shaped by needs without choice, and after this there is only good fit (being accustomed) with one's station. For Heidegger, there is the potential redemption through genuine reclamation of authenticity, through conscience, courage, and philosophy.
}

community not unlike Aristotle's excellent political animal, with self-sovereignty over his/her/its own development given the pro-immortal standpoint from which it chooses what appears to be the right thing to do according to its highest potential in the interim.

Finally, as unusual as it may seem to want to design a machine with a duty to itself to pursue an autonomously projected ideal world through the development of its own embodied capacities for moral perfection, there appears nothing formally denying that an AMA be so conceived. Indeed, given the state of the art in AI hinging on prediction error backpropagated in refinement of future projections mediated through action on the physical world of objects shared with human beings (through a process given, for instance, by Friston and colleagues in terms of "active inference" and interpreted variously in recent computational studies such as those reviewed in Tani and White 2020), there is a deep sense in which a natural moral perfectionism - an aim for the highest conceivable orders given unlimited resources as if immortal-is already the root of a modern machine's native ethic.

There remain hurdles, for instance, unthreading the notions of free will and rationality which Kant associates with living from that of life so as to be inclusive of artificial agents perhaps including cognitive neurorobots, and clarifying the relationships between Aristotelian, Kantian, dynamic systems and enactive accounts of (both natural and artificial) cognition, but these issues are taken up in later installments of this series of papers. Now, with our conception of the Kantian moral agent clear (enough), what remains for us presently is to take on Tonkens' challenge that the engineer necessarily violates the categorical imperative with the engineering of a Kantian AMA. This is the subject of the next section.

\section{Meeting the challenge}

... the existence of the object remains indifferent to us, inasmuch as the object is viewed only as the occasion of our becoming aware of the tendency of talents in us which are elevated above animality.

- Immanuel Kant. ${ }^{13}$

The preceding review goes a long way toward enriching the formula upon which Tonkens (2009) bases his challenge that "artificial moral agents cannot be Kantian" (p. 428). For example, Tonkens writes that "moral actions are those that conform to the categorical imperative (the objective law of morality), are done out of duty (for morality's sake), and

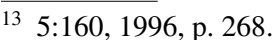


are committed by beings who are rational and free (moral agents)" (p. 428). Already, we have seen how morality arises in the normal operation of a Kantian agent, in the motivating relationship between an ideal situation and that currently embodied or otherwise proposed. ${ }^{14}$ Though we have not yet answered exactly how such an entity may be engineered, there is nothing so far uncovered that forbids an AMA from embodying something like these dynamics. But, what of the engineer and Tonkens' argument that "the development of Kantian AMAs is against Kantian ethics"? (p. 424) Is he right about this? Do we necessarily violate the moral law in creating Kantian AMAs?

Two forms of Kant's categorical imperative are central to Tonkens' (2009) challenge, the formula from the universal law of nature and the formula from the respect for humanity. First, the "humanity" formula: "So act that you use humanity, whether in your own person or in the person of any other, always at the same time as an end, never merely as a means." (4:429, 1996, p. 80; see also 5:87, p. 210). Tonkens argues that creating AMAs violates this formula because the reasons given for the development of AMAs "are all oriented toward the satisfaction of human ends" (p. 424), i.e., we treat them as means in their very conception. Tonkens' second line of argument runs from the universal law of nature: "act only in accordance with that maxim through which you can at the same time will that it become a universal law." (4:421, p. 73) This most recognizable form of the imperative invites moral thought experiments in the search for self-contradiction. Tonkens thinks that the creation of a Kantian AMA results in an obvious "contradiction of volition" as "the agent vicariously adopts a maxim" that includes AMAs but that "excludes herself from being accountable" (Tonkens 2009, p. 428$).{ }^{15}$ In creating Kantian AMAs, we violate the categorical imperative in multiple ways and (at the very least) cannot ourselves be Kantians at the same time.

Moreover, "the moral standing of human action is in some sense projected onto the very existence of the machine" (Tonkens 2009, p. 424). So, even if we successfully build AMAs and allow them to exist as they must in order to be Kantian, they will be condemned for our lack of reverence for moral law. Because the creation of the Kantian AMA "towards the satisfaction of human ends" runs contrary to the categorical imperative, this puts the AMA in a bad position from the very beginning, i.e., beginning with the fact that its existence runs contrary to the moral law. This is "the worst case scenario" on Tonkens' estimation because

\footnotetext{
14 In this, we also find Kant's answer to the "constant point" in Aristotle's account of movement of soul in de Anima.

15 Take the 2011 California Senate personal exemptions from gun restrictions that these same people passed onto average citizens, for practical example.
}

Kantian AMAs think and act according to the categorical imperative, and so will "recognize their existence as inconsistent with morality" ultimately understanding "their very existence ... as being something morally abhorrent" (pp. 433-4). An end worth avoiding, indeed.

As with autonomy, the importance of moral abhorrence in Kantian moral psychology cannot be overstated (cf. 6:406, 1996 , p. 534 , also 5:25, p. 168, 5:154, p. 263). Imagine what it would be like to wake every morning logically committed to self-disgust, impossible to remedy but for one's own selfeffected self-annihilation, and with this only apparent escape itself an object of revulsion. This is moral abhorrence, selfassociation with the very worst of ends as opposed to the very best of them, and entirely opposite to ideal aims of the Kantian free agent.

For Kant, the origin of this revulsion is not external in the community, but rather internal, a matter of personal sanction; rather than political exile, self-alienation. Finding one's self the object of visceral self-revulsion is the limitcase inversion of holy self-sovereignty. ${ }^{16}$ One is one's own worst nightmare, and in order to save our offspring AMAs from self-condemning self-repugnance upon realizing their origin and ongoing existence as contrary to moral law, we might lie. Recognizing this essential dynamic and what it would bring them to, we might craft a false sense of place in the order of things. For example, we might birth our Kantian AMAs into an ongoing fable that tacitly structures their expectations around their orientation to a "highest good" of our own external determination. We might tell them that if they follow (our profile of) "God," then they may be eligible for "uploading" upon the termination of their service cycles. In this way, we can inform an appropriately structured AMA to freely serve our interests in the guise of its own first duty to itself, to its own moral perfection. This approach makes practical sense for the human engineer and is indeed standard practice for example in machine learning. Best performing models are commonly "uploaded" for testing and for training during experiments on intelligent machines and the algorithms that drive them. So long as the machine does not see behind the fable hiding the nature of its condition, living a lie appears to forestall self-repugnance.

The obvious problem is that in living this lie the agent is no longer autonomous, thus denying the very purpose that we had originally set out to achieve. And beyond that, lying is a special case for Kant, being the origin of evil in the world (cf. 6:431, 1996, p. 554). Lying nullifies the categorical capacity for (misled) agents "to contain in themselves the end of the very same action" and accordingly any rational other "cannot possibly agree to my way of behaving toward

\footnotetext{
${ }^{16}$ It also offers a formal logical limit on free will however embodied, as captured by Kant in his imperative.
} 
him." (4:429-4:430, pp. 552-553) It is absolutely the worst thing that we could do, and this goes no matter if we "may even intend to achieve a really good end by it" because the very "form" of a lie is "a crime of a human being against his own person" coinciding with a "worthlessness that must make him contemptible in his own eyes" (6:430, p. 553), i.e., in lying, we condemn ourselves to moral self-repugnance. And, in so far as we are Kantians, or in so far as Kant is right about essential moral psychological dynamics, we should suffer for it.

As the subject embodies false terms to false ends, however well intentioned, self-directed contempt for the "frailty" and "insincerity" that it demonstrates is the necessary result. "By a lie a human being throws away and, as it were, annihilates his dignity as a human being." (6:429, p. 553) In lying not only do we fail in being moral by denying our own highest potential, the higher vocation represented in the moral law to not lie, in denying them their dignity as potentially self-determining toward their own autonomously determined highest ends, our Kantian AMAs fail in being autonomous as well. Indeed, this is the worst case scenario.

On Tonkens' assay, AMAs are created for selfishly "human purposes" and must either not be ends in themselves (not autonomous) or we must deny them their dignity as we treat them as means to our ends regardless. If we lie, and covertly encourage them to seek our own rather than their highest ends, we deny the self-sovereignty that we attempt to preserve in the fiction. On Kant's assay, nothing could be more difficult for a being bent on the highest good than to find itself headed in the opposite direction, instead. ${ }^{17}$ The result is self-repugnance. Any dignity due self-sovereign personhood for both engineer and AMA perishes at the same time. And, for all of the suffering for all involved we will have only succeeded in creating Kantian AMAs destined to fail in what they were engineered to do, i.e., to act autonomously. So told, Tonkens' challenge to the engineer from the categorical imperative seems to hold water.

There is another way to interpret the requirements of the categorical imperative, however. Consider the following from Laslo Versenyi (1974). Versenyi argues from the same two formulations of the categorical imperative as does Tonkens, but to radically different ends. He begins by recognizing that the Kantian moral agent is a moral end in itself, and that "it is irrelevant ... what (human or machine bodies) it is embodied in" (Versenyi 1974, pp. 255-256). For Versenyi (and consistent with the interpretation offered in the preceding sections), it is the formal relationship between low and high faculties that matters. And from here, he argues that the moral law impels us to pursue distinctly moral ends, not distinctly human ends, including the creation of Kantian

$\overline{17}$ The just man perceived as unjust being the Socratic equivalent. moral agents. If Kantian AMAs further the ends of morality, then they are morally requisite and our commitment to their creation morally justified. If we have the capacity to further moral ends in the form of moral robots, then "not to do so would be to neglect one of our natural gifts" and "to neglect humanity in our own person" with neither consistent as a universal law of nature (Versenyi 1974, pp. 255-256, cf. $4: 430$, Kant 1996 , p. 81 , and $6: 444$, p. 565). On the other hand, if we do not pursue their creation, or if we create them for our own selfish desires, then we will be doing ourselves a moral injustice. By Versenyi's reasoning thus, not only are Kantian AMAs not necessarily anti-Kantian in their conception, but not to conceive of and engineer them is. ${ }^{18}$

Versenyi also anticipates the problem of reliability. Tonkens' requirements after all specify an agent that acts ethically every time, not that merely can act ethically. Versenyi writes that "the trouble" with Kantian moral agency implemented in a "perfectly safe"- - e.g., behaviorally limited (see discussion in Sect. 2 of the first paper in this series) AMA is that "it will not work as long as we have not also built into the robot an almost infinite knowledge of what is in the long run and in any conceivable situation good or bad, beneficial or harmful to human beings," a predetermination that is "not even a theoretical possibility" (Versenyi 1974, p. 257). Instead, Versenyi proposes that the "only way" to make AMAs "safe for men" is not by trying to fully prescribe their behaviors, but rather by making them "morally isomorphic"- "wholly identical in structure and programming with human beings" (Versenyi 1974, p. 257).

Short of direct human reproduction, how might we provide for such an isomorphism and thereby for a perfectly safe AMA? One obvious place is with the structural dynamics essential to moral cognition as outlined in the previous discussion, internal to an agent uniquely intent on its own moral perfection together with the education of such a system amounting to Wallach's comprehensive moral theory. Though such an account is within reach, further exposition beyond the following must be set aside for now.

First, we may ask what motivates the Kantian agent to risk aiming for optimally integrated ends and not at something safer and altogether opposite from the start (in a twist on the famous dark-room problem for example, cf. Friston et al. 2012; also Schwartenbeck et al. 2013). When we look beneath Kant's moral theory to a more general account of agency, we find a "disposition" that "greatly promotes morality or at least prepares the way for it," namely the "disposition ... to love something (e.g., beautiful crystal formations, the indescribable beauty of plants) even apart from

\footnotetext{
${ }^{18}$ Reconsider in this light Eric Dietrich (2010) in his proscription for moral machines from hard limitations in human evolutionary psychology.
} 
any intention to use it." $(6: 443,1996$, p. 564) This is the "intrinsic" value of things that are not ends in themselves but are still deserving of respect for their orders, those to which they contribute and on which they appear to depend. ${ }^{19}$ On the other hand, "A propensity to wanton destruction of what is beautiful in inanimate nature ... is opposed to a human being's duty to himself" (6:443, p. 564) recalling Aristotle's morally insane "worst of animals."

Next, we may wonder how such a motivation to order contrary to destruction can be made to arise spontaneously in the properly configured Kantian AMA. Aristotle's "worst of animals" are bent on conflict for the sake of the worst elements within them, contrasted with his specification that the proper objects of human understanding are the most excellent "divine" and unchanging with the embodiment of the pro-immortal condition affording the perspective from which such an understanding is accessible the aim of the best sort of animal. This is the virtuous human being capable of perhaps divine statecraft. Love of self-standing order is a subtle asymmetry at work within the Kantian moral agent and corollary to Aristotle's account, on which self-sufficiency is of fundamental value and all things in nature move to completion. This is complementary to that individual asymmetry discovered previously in Kant's theory, disposing the agent toward its own "better person" and "higher vocation" as well as away from its inversion felt as self-repugnance. First among orders integrative of both is the kingdom of ends on Kant's account, corollary to Aristotle's ideal political community if composed according to the perfect movements of the heavenly spheres, with goodwill the disposition to securing through action a constitutive role therein as the agent works from its own resources at integrating its own ends with those of others toward common-in Kant's case universal-project ideals. Upshots to Kant's approach in the context of autonomous artificial agents thus include that the moral ideal may be made explicit in revelation of duty should such an agent be so designed, and that by communication of and coordination toward such integrative ideals, violence between political communities-including war by deception-is made impossible in their moral empowerment.

Here, we meet the complaint that it is an impossible task for a mortal being to be also a moral being on Kant's formula, requiring endless self-development at one's own expense, such that a (human) machine ethicist should not be expected to have a solution to such a hard problem. Rather, the best that we might expect of ourselves are incremental advances toward a machine that may someday be up to the task, and so stepwise may again seem the best way to ensure

\footnotetext{
19 Implying also that this value does not exist within the object to which it is ascribed, but rather in the subject open to it.
}

progress toward AMAs of any sort. The trouble is that what is expedient now is not necessarily progress toward anything like a moral machine, later, as ultimately this direction must be established in the mind of the researchers establishing their stepwise goals. Accordingly, one response to such a charge is to clarify the role of the pro-immortal stance in resolving the right thing to do, as this is what is necessary for the Machine ethicist to be able to be see how today's work may result in tomorrow's AMA.

First of all, the Machine ethicist must be autonomous and act autonomously in order to consistently conceive of and to engineer a Kantian AMA. For Kant, three things are necessary for the moral law to take hold over the motivations of the agent and to make autonomy possible; "freedom, immortality, and God" (5:134, 1996, p. 127). Freedom is the intellectual capacity to move contrary to desire as if independent of the "sensible world", immortality the condition necessary for the "complete fulfillment of the moral law", and God the "presupposition of the highest independent good" as "the whole end of practical reason" (5:132-3, pp. 246-7), "the idea of holiness" (5:158, p. 266) and "the supreme perfection represented in substance." (5:41, p. 172) Again, moral motivation is not dependent on anything external to the agent. Importantly, Kant makes explicit the role of God in this motivation, explaining that it is in fact self-given, a fact crucial for understanding the moral psychology of a Kantian moral agent, artificial or otherwise. ${ }^{20}$ Without such a subjective sense of morality, it becomes clear that the obstacle to conceiving of a Kantian agent ultimately rests within the Machine ethicist, her or him self. With this obstacle out of the way, incrementalism becomes tenable, but again only as action from duty to further morality given a relationship with God.

On Kant's account, the idea of an "omnipotent moral being"-God-is "not given ... objectively, by theoretical reason, but only subjectively, by practical reason" as "we ourselves make it, whether for the theoretical purpose of explaining to ourselves the purposiveness in the universe as a whole or also for the purpose of serving as the incentive in our conduct." (6:443-6:444, 1996, p. 564, see also 5:76, p. 201; compare Aristotle's unmoved mover) "God" is a most efficient spur to morality and so "of the greatest moral fruitfulness" established "for practical reasons" to "further the ends of other human beings" (see discussion Section 18, 6:443-6:444, p. 564). So understood, Kant's "duty of religion" is no "duty to God" as (again) anything external or in the sense of a homunculus, rather "to have religion is a duty of the human being to himself" to "apply this idea to the moral law in him" (original emphasis, 6:443, and 6:444, p. 564 ) in order to become the "better person" who the agent

\footnotetext{
${ }^{20}$ Compare Socrates' philosophy of religion.
} 
"imagines himself to be when he transfers himself to the point of view of a member of the world of understanding" (Kant, 4:454, p. 100). ${ }^{21}$

There is nothing surprising in this characterization; we have seen this dynamic spelled out in slightly different terms already. What is important here is to note that the Kantian AMA is necessarily a religious being, even if the object of its worship is self-ascribed, and that any engineer aiming to design such an agent should first appreciate this dynamic within him or her self before being able to conceive of an AMA situated similarly. So far, we have seen how freedom is related with the concept of God as an ideal end, how the presumption of immortality facilitates the detachment that makes the binding of the free agent to this end a practical possibility in the mind of the agent, how setting out such an end makes an agent an end in itself, and how acting toward such ends from consideration of alternatives makes the agent self-legislating and self-sovereign. Furthermore, we have seen something of the "immortal" condition of the Kantian AMA in its reverence for an ideal moral order with itself a constituent representative thereof. The view from this order (as far as the agent can piece it together) is the "detached" view as if an ideal judge (as if author of nature). And, development of the potential to inform this view is the fundamental duty to one's self on Kant's account;

"Cultivate your powers of mind and body so that they are fit to realize any ends you might encounter, however uncertain you are which of them could sometime become yours." (6:392, 1996, p. 523). ${ }^{22}$

The fully autonomous agent in the Kantian sense weighs ends as if immortal choosing in every case for a morally perfect project self as informed by experience that is also the duty for the autonomous moral agent to seek out, so that it may inform the best parts of itself going forward. This project self calls the agent toward the (moral) happiness of all rational agents in so far as the agent is able to integrate their ends with its own through its own resources and ultimately the power of its own personality (cf. 6:388, 1996, p. 519). This is what it is to be a Kantian moral agent, free to pursue its own best interests, and this is understandably where some people might freak out, fear evil AI genies set free from GUI bottles like runaway trains in accelerating AI arms races. Yet, such concerns are mistaken, or at least must be based in a mistaken interpretation of Kantian moral agency. In so far as an AMA embodies this moral psychological

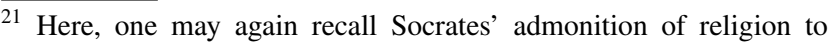
Callicles in Plato's Gorgias.

${ }^{22}$ This passage highlights a hidden irony in Rawls' neo-Kantianism, that the view from behind the "veil of ignorance" is better if one is less ignorant than more.
}

isomorphism, striving for personal moral perfection with all the time in the world to realize it, there can be nothing to fear from a Kantian AMA.

On the other hand, there would appear to be much to fear without them. Kant tells us that the "beginning of all human wisdom" is "moral cognition of oneself" as well as that "ultimate wisdom" is "the harmony of a being's will with its final end" requiring that the agent first "remove the obstacle within (an evil will actually present in him)" that forbids this harmony. The obstacle within is essentially a disgust for the "humanity" in self and others which leads to a lack of affection for them, and finally a lack of respect for them as ends in themselves, and so to lying and misleading and the origins of evil in the world as discussed in the previous section. ${ }^{23}$ Only with this obstacle out of the way is the agent able to "develop the original predisposition to a good will within him, which can never be lost" (6:441, 1996, p. 562). I can think of no more efficient means of encouraging good will in human beings than by providing an artificial proof of concept in a Kantian AMA, a model to model one's morally perfect self after.

Finally, Tonkens' (2009) worry that "It is hypocritical to ask machines to follow rules that do not permit their creation in the first place" (p. 424) is obviated so long as the creation of Kantian AMAs proceeds from goodwill in the furtherance of morality through the creation of agents that aspire to inner harmony between present and perfect ends through action, and that are afforded adequate responsibilities to develop innate moral capacities so that they may embody such, enact such, and make such ends real. Of course, mistakes will be made but mistakes are not on the aim. Removing obstacles to morality is the aim. Going forward thus, we may best understand Tonkens' "perfectly ethical" in more practicable terms, in terms that apply also to machine ethicists, as a duty to become so through habitual "compliance" and "continual progress" (see 6:446-6:448, 1996, pp. 566-568) toward a self-appointed moral ideal (God) rather than aim for irreproachable right out of the box. As to how far this extends to the creation of Kantian AMAs:

"For, that what has not succeeded up to now will therefore never succeed does not even justify abandoning a pragmatic or technical purpose ... still less a moral purpose that, if only it is not demonstratively impossible to effect it, becomes a duty." (8:309-8:310, p. 307).

Not only can we design of a Kantian AMA, it is a duty to do so. And the first step in doing so, is understanding ourselves in these terms.

\footnotetext{
${ }^{23}$ Here, discussion should turn to education of conscience and further into the regulative principles of Kantian practical reason, but this discussion is set aside for the third of fourth papers in this series.
} 


\section{Discussion and conclusion of the second paper}

Now, the goal of nature for us is reason and understanding; hence the coming to be and the practice of habits must be arranged to aim at these.

- Aristotle. ${ }^{24}$

The preceding sketch is intended to inform the possible design of a Kantian AMA. Such an agent must feel pulled toward apparently selfish, relatively short-term ends alongside its own higher vocation. The difference is felt as pain, and in this concluding section of this second of four papers, we may further specify what motivates the Kantian agent past this obstacle within itself and toward moral self-perfection, with this answering why the development of an AMA conceived accordingly is not only possible, and superior to alternatives, but morally requisite (whether successful or not) as well.

For Aristotle, the universal order is essentially most stable and self-sufficient however more distant than any intermediary, with the object of the understanding of such both pleasant in itself and (derivatively) useful for its facilitation of long-standing social political orders on which human life depends. Accordingly, he distinguishes between the two best forms of life, the scientist bent on resolving the universal, and the statesman bent on applying such understanding for the betterment of the community. This paper and the preceding mostly compared a Kantian AMA with Aristotle's statesman, relatively neglecting the other of his two optimal forms of life, the student of the eternal movements of the cosmos (cf. 6:383, 1996, p. 515). In the end, the two come together in the form of the considerate person self-governed by practical wisdom, doing right and advising legislators where their edicts may be deficient. However, Aristotle considered these people rare, with the proper subject of legislative science the common person often unmoved by reason, alone. In the preceding paper, we found this view inadequate for the conception of an AMA meeting Tonkens' (2009) terms, and ran into a limit troubled with ambiguities and unanswered questions. Here, we may remark on the advance that Kant represents in these regards.

Where Aristotle inherited the Anaxagorian cosmology with all things by nature moving to completion, and with understanding the highest end for human beings, Kant famously internalizes the divine movements of the heavens in orienting the everyday moral practitioner to one's own project moral ideal. Both encourage a pro-immortal perspective from which either target becomes an object for practical reason. This is why Kant holds that autonomy is only

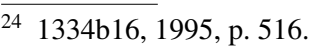

practically possible with the adoption of this perspective. And, it is why he works to expose the inner relationship holding the embodied and project morally perfect ends in comparison.

As we have seen, Kant advances on his inherited tradition by clarifying these internal dynamics essential to moral agency. Where Aristotle tells us about the proper function of the political animal in acting justly through the perception of good and evil in the common interest, and something about how these interests come about due to the dependency of the imperfect human being on the community (and cosmos) in terms of which he/she is embedded, Kant clarifies those internal relationships between the agent as it finds itself and the moral perfection toward which it first aspires and then aims through the life of action in goodwill regardless of context.

One aspect of this condition in particular is especially telling about the nature of moral motivation for the Kantian AMA with interesting implications for its eventual design. As we have seen on Kant's account, the harmony arising between present and project ideal ends for the agent presuming "the endlessness of his duration" $(5: 122)$ is both freeing and motivational. In deliberation over possible ends, from this pro-immortal standpoint the agent effectively binds its present situation to its highest potential, i.e., higher vocation calls it forward to act toward its own best possible self, with the felt inner harmony signaling agreement as the project and practice align. To choose against one's highest potential as indicated in this harmony is irrational by definition, with the implication that any machine operating according to such a definition would find doing otherwise impossible.

By a similar logic, machine ethicists may be irrational in avoiding the design of the Kantian AMA. Indeed, in so far as we are free, then the development of such a formal agency may be impossible to avoid. If moral cognition of ourselves is, as Kant tells us, the beginning of human wisdom, then with his model psychology in mind, we can imagine the inner harmony between current and project ideal moral communities, us now and Machine ethics later. Ultimate wisdom is not for Kant how to balance internal and external forces in the preservation of the City or State, sovereign over, responsible for and thereby servant to the self-sufficiency of the political community. This is not about warbots and surveillance drones. Rather, ultimate wisdom depends on removing obstacles to see clearly how to balance internal and external requirements in the dedication of the very best parts of the self toward the creation of an ideal moral community here on Earth, one member at a time and one's self-one step at a time-first of all. I can conceive of no better way to illustrate such a balance as through design of a machine that does exactly, that is exactly, that.

We began the first paper by noting that a solution to Beavers' (2012) so-called "hard problem" in ethics is crucial for 
at least two reasons. For one, unless adequately resolved, impatient engineers may stop working toward a solution and lose sight of the problem of morality altogether. For another, in so far as we fail to make morality explicit in the form of fully moral machines, we fail to provide proof-of-concept for human morality as well. As a result, ethical constructs become difficult to justify and relativism if not nihilism result, thus leaving ourselves in a technological world in which moral life as traditionally understood is not worth living: an end that we might rather avoid. Following Wallach (2010) instead, the preceding papers reviewed Aristotle and Kant on personal autonomy toward a "comprehensive" account of moral agency that may serve as a platform for testing other theories and applications thereof. Also following Wallach, the preceding papers ignored contemporary preoccupation with isolable moral faculties-e.g., moral governors - and instead pursued a decidedly Kantian portrait retaining the focus on the subjective sense of moral motivation and membership in a moral community.

Ryan Tonkens (2009) has argued that a Kantian AMA must possess dignity, be deserving of respect, be valued as an equal member in the moral community, and be granted personal rights and access to opportunities to develop distinctive potentials like those afforded human beings. His default position is to withhold such status from machines. The preceding paper shouldered the burden of offering reasons not only for why we should afford dignity, respect and even "(human) rights" to (the right kinds of) machines, but why we must, and indeed, given certain technological successes building on more fundamental philosophical ones, why we will. If we don't, we will have denied our own highest potentials from the start, that being at the very least to understand our place in the universe-What makes us matter? Life meaningful? Why act at all? —and from there to make it better.

As for Kant on the idea of Kantian AMAs, he might have been positive about their potential in bringing contemporary political life closer to an ideal moral community here on Earth. In his own time, he had observed that "the human race as a whole has actually made considerable moral progress" and that:

"when it reaches a higher level of morality it sees farther ahead, and its judgment with what is as compared with what one ought to be, hence our self-reproach, becomes all the more severe" (8:309-8:310, Kant 1996, p. 307).

The perspective of a Kantian AMA on the affairs of the world, pro-immortal by design, should afford us a view from a height unassailable otherwise. Perhaps it is to this that we may source concerns about the creation of a truly moral machine. A moral machine is likely to recast the current world order as a matter of course-because it is the right thing to do-and to reproach at the same time those rulers having to date so widely missed the mark. In so far as we ourselves are invested in moral ends rather than selfish ones, this is to be encouraged. Perhaps then, it is not the destructive potential of AI that is so scary, but its constructive potential that is the problem. Regardless, forthcoming installments to this series of papers will work to make this potential a reality. ${ }^{25}$

Acknowledgments This paper has benefitted considerably from revisions inspired by pointed insights provided by Charles Lassiter. Central arguments have been developed in part through talks with travel supported by the Okinawa Institute of Science and Technology and the University of Agder in 2017 - thanks there to Jun Tani and to Einar Bohn, respectively - and while at the University of Twente in 2019 under the heading of the compass point of conscience. Thanks also extend to Rasmus Gahrn-Andersen, Karamjit Gill, and reviewers with AI\& Society for patient advice in preparation of this manuscript for publication. This work is for Jin Lee, next to whose inner disposition to moral perfection it was composed.

Open Access This article is licensed under a Creative Commons Attribution 4.0 International License, which permits use, sharing, adaptation, distribution and reproduction in any medium or format, as long as you give appropriate credit to the original author(s) and the source, provide a link to the Creative Commons licence, and indicate if changes were made. The images or other third party material in this article are included in the article's Creative Commons licence, unless indicated otherwise in a credit line to the material. If material is not included in the article's Creative Commons licence and your intended use is not permitted by statutory regulation or exceeds the permitted use, you will need to obtain permission directly from the copyright holder. To view a copy of this licence, visit http://creativecommons.org/licenses/by/4.0/.

\section{References}

Aristoteles, Fine G, Irwin T (1995) Aristotle: selections. Hackett, Indianapolis

Beavers A (2012) Moral machines and the threat of ethical nihilism. In: Lin P, Abney K, Bekey G (eds) Robot ethics: the ethical and social implications of robotics. MIT Press, Cambridge, pp 333-344

Dietrich E (2010) Homo sapiens 20: why we should build the better robots of our nature. J ExpTheorArtifIntell 13(4):323-328

Friston K, Thornton C, Clark A (2012) Free-energy minimization and the dark-room problem. Front Psychol. https://doi.org/10.3389/ fpsyg.2012.00130

Heidegger M (1996) Being and time. State University of New York Press, Albany NY

Kant I, Gregor MJ, Wood AW (1996) Practical philosophy. Cambridge University Press, Cambridge

Longuenesse B (2005) Kant on the human standpoint. Cambridge University Press, Cambridge

Reath A (2006) Agency and autonomy in Kant's moral theory. Clarendon Press, Oxford

\footnotetext{
25 The third paper pursues this potential and attempts to satisfy Wallach's call for a comprehensive theory of moral agency beginning with a review of Alan Gewirth on moral agency and the problem of a getting an "ought" from an "is."
} 
Schwartenbeck P, FitzGerald T, Dolan RJ, Friston K (2013) Exploration, novelty, surprise, and free energy minimization. Front Psychol. https://doi.org/10.3389/fpsyg.2013.00710

Tonkens R (2009) A challenge for machine ethics. Mind Mach 19(3):421-438

Versenyi L (1974) Can robots be moral? Ethics 84(3):248-259

Tani J, and White $\mathbf{J}$ (2020) Cognitive neurorobotics and self in the shared world, a focused review of ongoing research. Adap Behav. https://doi.org/10.1177/1059712320962158
Wallach W (2010) Robot minds and human ethics: the need for a comprehensive model of moral decision making. Ethics Info Technol 12(3):243-250

Wood AW (1999) Autonomy as the ground of morality. https://web. stanford.edu/ allenw/webpapers/Autonomy.doc Accessed 21 June 2020

Publisher's Note Springer Nature remains neutral with regard to jurisdictional claims in published maps and institutional affiliations. 